\title{
A 2x2=4 hobbyhorse: Mark Blaug on rational and historical reconstructions
}

\author{
HARRO MAAS \\ Utrecht School of Economics
}

\begin{abstract}
Over time, Mark Blaug became increasingly sceptical of the merits of the approach to the history of economics that we find in his magnum opus, Economic theory in retrospect, first published in 1962, and increasingly leaned to favour 'historical' over 'rational' reconstructions. In this essay, I discuss Blaug's shifting historiographical position, and the changing terms of historiographical debate. I do so against the background of Blaug's personal life history and the increasingly beleaguered position the history of economic thought found itself in after the Second World War. I argue that Blaug never resolved the tensions between historical and rational reconstructions, partly because he never fleshed out a viable notion of historical reconstruction. I trace Blaug's difficulty in doing so to his firm conviction that the history of economics should speak to economists, a conviction clearly present in his 2001 essay: "No history of ideas, please, we're economists".
\end{abstract}

Keywords: economic historiography, rational reconstruction, historical reconstruction, Whig history, constructivism, economic methodology

JEL Classification: A20, B20, B31, B41

On the 12th of December 1998, Mark Blaug wrote a short letter from his house in Devonshire to Paul Samuelson, in his usual longhand.

Dear Paul,

Are you imposing your $2 \times 2=4$ hobbyhorse on anyone, you ask. Yes of course: students. You remain an unrepentant rational constructionist. Nothing wrong with that if it comes to understanding the logic of economic arguments, but possibly, no invariably misleading

AUTHOR's NoTE: Thanks to Ruth Towse, who graciously sent me Mark Blaug's correspondence, Roger Backhouse, D. Wade Hands, Marcel Boumans, Matthias Klaes, and the participants at Erasmus University Rotterdam, the ESHET annual conference in St Petersburg, and the HES annual conference at Brock University, Canada, in sessions in commemoration of Mark Blaug, for comments and input, orally or in writing. Thanks also to two anonymous referees who made me decide to substantially alter an earlier version. The usual caveat applies. 
when it comes to historical reconstruction. Yes, I do want to get as close as possible to what 1776 readers thought of Smith-and that's my hobbyhorse!

Best wishes,

Mark Blaug.

Mark responded to a letter of Paul Samuelson one week before in which Samuelson described his own approach to the history of economics as rational-reconstructivist and Whig.

These days for something to be called Whig History is on Monday, Wednesday and Friday a compliment, on the rest of the week a slur. My usual practice, which some might call WH, is to describe a scenario that some readers will agree approximates a scenario that various 1720-1870 writers have commonly contemplated. (Most of them were sometimes incoherent and on different pages seemed to write down partially inconsistent words).

I then work out what must be the properties of that scenario: must be in 1817; must be in 350 B.C. (under the scenario's specifications about homogeneous labour, heterogeneous capital goods, heterogeneous or homogeneous fixed-supply land(s); non collusive, free-entry with imitation; and usually no interesting imperfect competitions); must be in 1998; must be in 2998. [...] It does not matter whether I use 1910 graphs; or 1890 mathematics; or few syllable words in French, English or Choctaw. I am not making a rational reconstruction of Jones ["Of course you do!" Blaug wrote in the margin of the letter]. But later I may compare and contrast what Jones seemed to say about that specified scenario with my description. ${ }^{1}$

Samuelson continued to explain that he was pursuing his own intellectual curiosity and was not-like the pedigree of Whig history, the nineteen-century Whig historian Thomas Babbington Macaulay"imposing" his views on anyone. So what fault was there in his ' $2 \times 2=4$ hobbyhorse'?

This brief correspondence between Samuelson and Blaug summarizes in a nutshell an overarching theme in Blaug's career as a historian of economics. From this exchange of letters, Blaug's unconditional choice for historical reconstructions against Samuelson's defence of Whig history-that Samuelson equates with rational reconstructions-seems clear enough. But looking over his distinguished career, Blaug's preferences had shifted, just as the terms of debate had

\footnotetext{
${ }^{1}$ Mark Blaug's (unpublished) correspondence was kindly provided by Ruth Towse.
} 
done. Even in this short correspondence different labels abound that are by no means the same thing: rational constructionism, historical and rational reconstructionism or reconstructivism, Whig history. The first edition of Economic theory in retrospect (1962) started with the distinction between an 'absolutist' and a 'relativist' way of writing the history of economics, and clearly expressed Blaug's preference for the first. In the fifth and last edition (1996), published two years before his brief exchange of letters with Samuelson, he wrote that "in due course" he had come to have "second thoughts about both the choice between these two viewpoints" and about the terms of choice. Consequently, "relativism" and "absolutism" had become historical and rational reconstruction (Blaug 1996 [1962], xvii), and had prompted him to revise his treatment of some of the controversies in the history of economic ideas.

In this essay I will discuss Blaug's shifting historiographical position and the shifting terms of historiographical debate. I will do so against the background of Blaug's personal life history, that is heavily intertwined with the increasingly beleaguered position the history of economic thought found itself in after the Second World War. I will argue that Blaug never resolved the tensions between historical and rational reconstructions, partly because he never fleshed out a viable notion of historical reconstruction, and this despite his later leaning towards such an approach. I will trace Blaug's difficulties in taking historical reconstructions beyond foot stomping to his firm conviction that the history of economics should be a history of economic ideas that would speak to economists, a conviction he adhered to even as late as his historiographical essay of 2001 that bear the ominous title: "No history of ideas, please, we're economists".

\section{BLAUG'S WORK AND BACKGROUND}

Without any doubt, Mark Blaug was the most important Dutch-born historian and methodologist of economics. Among economists, he is best known for his Economic theory in retrospect, a textbook that went through five seriously altered editions from its first publication in 1962. Samuelson once wrote that at his visits to the libraries of Harvard and MIT he was struck by the 'revealed preferences' of students; the pages of Blaug's book were much dirtier by use than those of Gide and Rist, Roll, Spengler, and even than those of Schumpeter's The history of economic analysis of 1954 (see Samuelson 1987, 56). Historians of economics will 
also know Blaug from his Ricardian economics of 1958, the book version of his $\mathrm{PhD}$ thesis supervised by George Stigler and Terence Hutchison. Methodologists will know him from The methodology of economics: or how economists explain of 1980. Blaug produced an impressive stream of essays for scholarly journals, including his work in economic history, economics of education, and cultural economics. The first volume of the series of anthologies of economic essays-which he edited with Edward Elgar-was devoted to the historiography of economics. That is hardly surprising, since writing the history of economics was his enduring interest.

Mark Blaug was born on the 3rd of April 1927 in The Hague in a family from Austrian-Jewish origin. He grew up in Amsterdam in the 1930s (where he remembered playing with Anne Frank). His father ran a successful business in raincoats that was located at the Keizersgracht in the city centre, close to the (then) headquarters of the daily newspaper of the communist party. His family left the Netherlands in time. Blaug entered the United States via England and started studying economics at a time when the discipline fundamentally changed its direction. Econometric tests of theories on statistical datasets were first introduced in empirical research. Diagrams and mathematics became standard tools in the economist's toolbox. In addition, the large influx of soldiers in the American universities after the Second World War changed the character of universities and university teaching. These changes fundamentally influenced the way in which Blaug, brilliantly and ambivalently, approached the history of economic ideas in the postwar period.

After being denied tenure at Yale in the early 1960s, Mark Blaug left the history of economic ideas for some fifteen years and moved to London to work on applied research in educational and labour economics. He became acquainted with the work of Imre Lakatos, whose approach to philosophy of science made an impression on Blaug's own thinking about economic methodology-as witnessed from his The methodology of economics: or how economists explain of 1980, an intense exploration of the fruitfulness of Lakatos's notion of 'scientific research programs' in understanding the discipline of economics. He also developed an expertise in cultural economics, and the appointment of his wife Ruth Towse-an outstanding cultural economist-at Erasmus University in Rotterdam, brought him back to the Netherlands. 
By the end of the 1990s, he combined part time appointments at Erasmus University and the University of Amsterdam. In Amsterdam he was the third to occupy the chair of the Dutch historian and methodologist Joop Klant, after Neil De Marchi and Mary Morgan. The Amsterdam chair was one of the few self-standing positions in history and methodology of economics and recently fell victim to a severe reorganization of the economics faculty. This is a sure sign of the embattled position of history and methodology in contemporary economics. Be that as it may, Blaug's return to Amsterdam brought him back to the borough where he spent parts of his youth, close to the Hortus Botanicus and the Zoo.

\section{STUDENT OF GEORGE STIGLER}

Blaug's own history in economics started at Columbia University, where he wrote his PhD thesis on David Ricardo with George Stigler (and Terence Hutchison as second supervisor). Blaug started his dissertation work after receiving an unexpected offer of the Guggenheim Foundation for a research fellowship ("But I did not apply for it!", "Yes, you did"). ${ }^{2}$ The offer directly followed his forced resignation from his temporary teaching job at Queens College, New York in 1953 after he had signed a student petition in support of his colleague Vera Schlakmann who had fallen victim to the McCarthy committee on un-American activities because she refused to testify. The student-petition that asked for her reinstatement had to be signed by a faculty member that unsurprisingly proved difficult to find. As there was nothing in her teaching or behaviour that Blaug could think of as un-American, he simply could not refrain himself from signing. He did sign the petition in the morning and by $2 \mathrm{pm}$ the college president gave him an ultimatum: either resign voluntarily or be sacked (and blacklisted).

The offer of the Guggenheim Foundation showed that behind the scene people tried to save the careers of promising scholars like Blaug. He rented a small apartment at the back of the British Museum to read in the British Library on a daily basis. He remembered this as one of the best experiences in his life-and a life changing experience. Sitting in the British Library Reading Room, "reading, reading, reading, and taking notes"- that was the kind of life he wanted to live for the rest of his life (see Fountain 2007).

\footnotetext{
${ }^{2}$ These comments are from an interview with Blaug, see Fountain 2007. Blaug wrongly remembered the offer to be from the SSRC, see Backhouse 2012.
} 
Despite Stigler's position at the opposite end of the political spectrum (as a student, Blaug had communist sympathies) they got on very well. They shared a love for books, not just as objects, but to read them cover to cover. Both had uncompromising high academic standards and they shared an interest in the history of the field, especially in the work of David Ricardo. They certainly did not share the disdain for the "wrong opinions of dead men" that economists on John Maynard Keynes's authority attributed to Arthur Pigou. But Stigler's line in the second issue of History of Political Economy that "one need not read the history of economics-that is, past economics-to master present economics" (Stigler 1969, 217) well expressed the growing consensus that reading in the history of economics for an academic economist is a dead weight loss. And this, despite the niceties Stigler had to say about the intrinsic merits of studying the history of ideas.

Back in the United States, Blaug replaced William Fellner at Yale for his course in the history of economic ideas. The meticulous preparation of this course resulted in Economic theory in retrospect. Written as the textbook for which he is now best known, it did not earn him tenure. The Yale of the Cowles Foundation and James Tobin had lost interest in the history of the discipline, if it ever had any. We learn from Roger Backhouse's (2001) investigation of subsequent editions of the book how Mark Blaug became increasingly critical of formalism in economics-l'art pour l'art mathematical modelling that went untested-misconceptions about Adam Smith's most famous phrase, delusions about instantaneous market equilibrium at all times, and how he became increasingly sympathetic towards approaches in economics that aimed at doing justice to the context of the economists' ideas and to Austrian conceptions of the market as a process (see Davis 2013). Blaug moved from 'rational' to 'historical' reconstructions, a distinction that he came to prefer over the earlier distinction between 'absolutist' and 'relativist' histories of Economic theory in retrospect. The labels remained confusing and loaded with different connotations, bearing the marks of the different discourses they came from and we will see that Blaug never succeeded in clarifying them.

\section{HISTORY OF ECONOMICS IN AN AGE OF MODELLING}

Blaug's difficulties in clarifying the approaches to doing history of economics had everything to do with the momentous change of the economics discipline following the Second World War. Before the war, 
there was no clear distinction between the history of economic ideas and economic theory proper, and this despite Pigou's alleged dismissive remark about the wrong ideas of dead men. Especially, but not exclusively, in the Continental economic tradition, to do theory was to engage with the books and essays of predecessors; political economists of the past were as much part of economic discourse as economists of the present. Where a review of the literature nowadays is section one of a research paper, an obligatory rite de passage that serves to situate the paper's contribution to 'the field', after which the real theorizing starts, theorizing in the earlier days was essentially a bookish endeavour. In this earlier approach to theory, there was no neat split between theory and empirical data, rather theory and data were convoluted; economists synthesized past thinking and statistical and other observations to understand the questions at hand (Maas 2011). Books were the medium of thought, history of ideas a natural component of the profession.

It is perhaps important to note that this earlier approach to theory was not considered part of history; for an economist to engage with historical texts did not turn the economist into a historian, of ideas or otherwise. Rather, ideas that were voiced by historical actors were incorporated in contemporary thinking. Indeed, since John Stuart Mill's struggles with history (see De Marchi 2002), economists have boasted to have a method and principles that set them apart from the historian. The outcome was that an early twentieth century economist could still read Mill's Principles to think and theorize about the nature of contemporary business cycles, but did not think of himself in any way as a historian. Even once the distinction between theory and data started to settle in, someone like Wesley Clair Mitchell still canvassed past authors for their theories on the business cycles to opportunistically use their ideas to understand present data-e.g., in his Business cycles: the problem and its setting (1927).

After the Second World War such a bookish approach to theory became increasingly obsolete due to the modelling practices that emerged in the various top academic institutes and research institutes in the US. ${ }^{3}$ These modelling practices were far from uniform, but coincide in that theory became identified with the explicit statement of assumptions that were then used in a modelling exercise from which

\footnotetext{
${ }^{3}$ For the most recent account of the emergence of this multifaceted practice in economics, see Morgan 2012. See also Boumans 2005.
} 
conclusions could be derived. Economists increasingly lost the ability of how to approach a bookish text for theorizing. Mary Morgan recently quoted Robert Lucas on his experience in reading Keynes: "You had to have an intermediary to get close to the General Theory. Somebody had to help you get at it" (quoted in Morgan 2012, 221 n8). Such intermediaries became themselves models, such as the small model Hicks developed to understand Keynes. To understand the meaning of a bookish theory became to formally state its assumptions, preferably in mathematical form, and then to logically deduce its consequences.

The practical effect was that economists became engaged with models rather than with the texts of their predecessors. Mirroring the split in Victorian Britain of political economy in economic history and economics that followed on the marginalist revolution, after the Second World War an economist with a passion for books instead of modelling became a historian, and this is precisely how George Stigler-Blaug's thesis supervisor-defended the history of economics; as an antiquarian endeavour that might help train the fibres of the brain, but did not substantially help build economic theories. For economists, history of economics became the business of antiquarians. The history of economic ideas became only problematic when economists abandoned economic theorizing as an engagement with the ideas of predecessors and replaced this with a modelling approach to theory and an approach to history in which the ideas of predecessors were benchmarked in a vocabulary that modellers could understand and work with.

Mark Blaug geared Economic theory in retrospect of 1962 to the needs of this new generation of economists. Blaug included extensive reading guides to classics such as Adam Smith's The wealth of nations or Alfred Marshall's Principles of economics, and he presented the theories of past economists in the vocabulary of contemporary economists. His revised treatment of Keynes for the fourth edition of Economic theory in retrospect of 1985 is a good example. Rather than discussing The general theory itself, which according to Blaug would mean to indulge in endless discussions on 'what-Keynes-really-meant' (Blaug 1985 [1962], i), Blaug subsumed Keynes under the chapter heading 'macroeconomics' and examined the 'Keynesian system' in terms of the Hicks-Hansen income-expenditure model, that is, the IS-LM model-the model every economic student around 1985 would have been familiar with and would have been able to work through 
analytically. Blaug concentrated on the logic of the argument, that is, the logic stated in modern terms.

As indicated, in the 1962 introduction, Mark Blaug explained this approach in terms of the distinction between an 'absolutist' and a 'relativist' approach to the history of economic ideas. An absolutist approached the history of economics in terms of its theoretical and empirical progress, a relativist valued and explained economic ideas against the changing context in which they emerged. For an absolutist the focus was on assumptions and logical structure, not on ideas in context. According to Blaug, no historian of economics could be considered to fully maintain either an absolutist or relativist position. But the absolutist position was the more attractive. Even though there was the danger of judging old thinkers by modern standards, there was also, Blaug approvingly quoted Samuelson, the reverse danger for the relativist of not recognizing the same substance in the thoughts of past economists, "because they do not use the terminology and symbols of the present" (Blaug 1985 [1962], 1; quoting Samuelson). Blaug even wondered if a relativist position was not self-defeating. How were theories to be judged on their respective merits if they were all a "faithful reflection of contemporary conditions" (1985 [1962], 2). If by context was meant such diverse things as "Zeitgeist, social milieu, economic institutions and philosophical currents", Blaug concentrated in contrast on the "internal logic of theory" and doing so implied for the historian to "willy-nilly becoming an absolutist" (1985 [1962], 7).

Economic theory in retrospect thus served the needs, if any, of post-war generations of economists for history of economic ideas. Or perhaps one could better say the possibility of such a history in the post-war context. These ideas were treated in terms and in a method that was recognizable to the modern economist; in the modern analytical terms earlier economists were short of, but grasped at. The ensuing model was then investigated on the logical (and less so empirical) claims it entailed. This was an absolutist approach to the history of economics in two ways; first, it supposed there was progress of economic ideas in the direction of the present; and second, it supposed it was possible to isolate the kernel of past thinking that could then be examined on its logical structure. Claiming progress and examining logical structure are of course different things, but for Blaug they were (willy-nilly) connected because criteria for progress were found in the advancement of the logical structure itself. If we consider 
logical structure, we can then distinguish between the logical structure of a book or theory in its own terms and its logical structure in modern terms. During the 1990s, Blaug came to consider this last difference as one between 'historical' and 'rational' reconstructions.

The implicit assumption Blaug (and many of his contemporary economists) made in Economic theory in retrospect was that the vocabulary of modern economics was more transparent and therefore an improvement on the vocabulary of its predecessors. Progress was implied in logical structure. Clarifying logical structure could also improve original texts that, otherwise, remained opaque. Examining the logical structure of a theory in its own terms was thus automatically subsumed under the examination of logical structure in modern terms.

A good example is the so-called 'corn-model' that Piero Sraffa distilled from Ricardo's Principles (see Blaug 1985 [1962], ch. 4, sec. 31). Sraffa's corn-model solved the determination of the rate of profit "in purely physical terms without entering into the question of valuation". However, "on balance" Blaug considered "that Ricardo never went so far as simply to assume that wages were entirely spent on wheat and that all manufactured products are luxuries which are never consumed by workers", and these two assumptions had to be made for the cornmodel to work. Thus, even though one could distil the corn-model from Ricardo's writing, this was not the model Ricardo himself had "in the back of his mind". For that reason Blaug considered Sraffa's "ingenious argument" a "rational reconstruction". But this left unexplained how a historical reconstruction of Ricardo would have looked like, and it certainly did not give a reason why a historical reconstruction would be superior to a rational one. To the contrary, Sraffa's exercise showed the limits of Ricardo's system.

\section{HISTORY AS AN EXTENDED PRESENCE}

The star example of an approach to the history of economics that highlights logical structure in modern terms was in fact not given in Blaug's Economic theory in retrospect, but by Paul Samuelson's so-called 'canonical classical model'. Samuelson, like Stigler, was educated in bookish fashion and Samuelson did not tire of emphasizing that he selfeducated himself in the mathematics that was scorned by economists at Harvard and Chicago. History of ideas was part and parcel of their disciplinary upbringing and actively pursued by both. But Samuelson approached the history of economics as he approached any other topic: 
What is the substantial question one can distil? Formulate that in a small coherent model. Look into the different scenarios that can be derived on its basis (and only look at the interesting scenarios among the many). State your conclusions. Possibly, look back at issues you left out that might complicate or alter your findings. It would make no difference to Samuelson whether his models were concerned with historical predecessors or with contemporary issues.

We can find this approach in his substantial economics papersthink of his multiplier-accelerator model of 1939, his joint paper with Stolper of 1941, his exact consumption-loan model of 1958, to give just a few examples-and in his papers in the history of economics as well. In his so-called 'canonical classical model' (1978) Samuelson claimed to have captured the essential elements of the theories of Smith, Malthus, Ricardo, J. S. Mill, and Marx (their 'cash value'). By concentrating on a world specified with "homogeneous labour, heterogeneous capital goods, heterogeneous or homogeneous fixed-supply land(s); non collusive, free-entry with imitation; and usually no interesting imperfect competitions", Samuelson $(1988,161)$ ironed out any substantial differences there might be between Smith, Malthus, Ricardo, Mill, and Marx, but also did not bother if these assumptions could be found in the original texts themselves. After all, he was not making a rational reconstruction "of Jones". But only creating a scenario that he then would use to see to what extent what Jones had to say about a specific question could be explained with his, that is Samuelson's, scenario. "Of course", Blaug wrote in the margins, Samuelson was making a rational reconstruction. Recreating old texts in the modern vocabulary of the economist became exactly what Blaug considered a rational reconstruction to be. Samuelson self-confidently labelled his approach to the history of economics "Whig history", and gave a vigorous defence of it in his keynote address to the History of Economics Society in 1987. When Cigdem Kurdas (1988) pointed out there was a difference in treating an author in his own terms and in modern terms, Samuelson ignored rather than confronted the evidence.

Kurdas concentrated on Samuelson's treatment of Smith. For example, Samuelson's assumption of constant returns to scale-a standard assumption of modern production theory-was nowhere to be found in Smith's The wealth of nations and in fact contradicted by the link Smith saw between the extent of the market and the increase in the division of labour. But also Adam Smith's observation that the 
"improvement of the productive powers" of agriculture "does not always keep pace with their improvement in manufactures" (Smith 1976 [1776], 16) was a "far cry from the inexorable downpull of land scarcity in the canonical model" (Kurdas 1988, 18). In response, Samuelson preferred to "keep Whig history honest". "Debating interpretations" was only an "adversary procedure of research" (Samuelson 1988, 161), and rather than opening cans of worms, Samuelson reaffirmed the assumptions of his canonical model as the only ones relevant for a modern economist.

Thus, Samuelson treated Smith, Ricardo, and other past economists very much as contemporaries, indeed just as (political) economists had done in earlier days, with the important difference that he no longer engaged in an interpretation of their words, but replaced them with the vocabulary and assumptions of the modern economist. Whatever Samuelson might write to Blaug in later years about the indifference of the language chosen for the conclusions derived-graphs of 1910, nineteenth century math, French, Choctaw, English-was merely rhetorical. The true litmus test was the language of the modern economist: homogeneous labour, heterogeneous capital goods, heterogeneous or homogeneous fixed-supply land(s), free entry with imitation, and no imperfect competition. Put that in a small model and see what happens. And this was, as Samuelson wrote in an exchange of 1974 with W. Baumol on the interpretation of Marx's transformation problem, for him the only way to treat past economists as contributing to the "collective house of knowledge" and not "as a historical deity or oddity". It was to "appraise" past theories as "a journal referee would treat any serious contribution" (quoted from Blaug 1990, 30).

For Samuelson "within every classical economist, there is to be discerned a modern economist waiting to be born" (1978, 1415). If history wanted to speak to the economist, the logic of an argument was to be explained in the language and the tools of the modern economist, no matter if there might be another way to approach the logic of a text. Again, in his keynote lecture to the History of Economics Society, Samuelson claimed he had captured "in one diagram what is held in common by Ricardo, J. S. Mill, Malthus, Marx, and Smith" (1987, 56). The implication of Samuelson's identification of early twentieth century diagrams, end of nineteenth century mathematics, and one syllable prose of French, English, or Choctaw, did not mean the logic of an argument itself could be historicized, but the contrary; Samuelson turned the history of ideas into something that was time and 
place invariant. Consonant with the move in the philosophy of science of the fifties and sixties, theory became general, time and place independent, its logic identical with what Thomas Nagel (1986) nailed down as the "view from nowhere" (see also Hands 2007).

History of economic ideas became the history of-in Kenneth Boulding's words - an "extended presence"; dead authors might be part of the conversation, even when they did not participate in it "directly" (Boulding 1971, 228). The difference with the earlier mode of theorizing is seated in the subordinate clause. While in earlier days economic predecessors were made to participate directly in the conversation, now they only did so indirectly, in the vocabulary of modern economic discourse. Samuelson contrasted the interests of the "honest Whig historian" with those of the "antiquarians", who did not contribute to modern analysis, but indulged their attention to the investigation of context and details of original texts that were irrelevant to the logic of arguments.

Contrasting antiquarianism with theoretical relevance meant that to put ideas in context was of no use for the economist. It was Samuelson's Whig historian, or rational reconstructivist approach that put any other approach to history on the defensive. Implied in Samuelson's notion of the Whig historian was perhaps not even progress, but irrelevance of any approach that did not contribute to contemporary theorizing. The tables had turned against bookish theorists. "After Samuelson, who needs Adam Smith?", as Kenneth Boulding put it in his contribution to first issue of History of Political Economy (1971). The meeting of the small group of historians in Britain in 1968, where the launch of this specialized journal for the history of economic thought was feared to increase the marginalization of historians within the economics discipline, was exemplary for the uneasy and beleaguered position historians of economics came to find themselves in. But it was modern theory that first defined them as historians, and then, as antiquarians.

\section{RATIONAL AND HISTORICAL RECONSTRUCTIONS}

In the first edition of Economic theory in retrospect of 1962 Blaug had self-confidently chosen sides with modern economics-with the rational reconstructivists (for an 'absolutist' instead of a 'relativist' writing of economics' history). There was a practical reason for this, even though I am not sure how heavy this weighed for Blaug. Intended as a textbook, Blaug could not just indulge in the texts of the classics, as he had enjoyed so much in the British Library Reading Room. He had to clarify 
their ideas to contemporary economics students, educated in the language of Samuelson's Economics (1948)-if not of the Foundations (1947). But Blaug fundamentally considered, just like Samuelson, that the logic of arguments was better articulated in the language of modern economics, and a consistent relativist position impossible to maintain. "Relativism" saw past theories as "faithful reflections of contemporary conditions, each theory being in principle equally justified within its own context" (Blaug 1985 [1962], 2). It is significant these words were still there in the fourth edition of 1985. Around that time Blaug's sympathies had started moving in the opposite direction towards historical reconstructions. The final edition of Economic theory in retrospect (Blaug 1996 [1962]) changed as a consequence, but it was transformed unevenly. Refined historical reading guides were followed abruptly by concepts and diagrams that were, if anything, rational, not historical, reconstructions. We find this same unevenness in his article on the historiography of economics of 1990.

This article was perhaps triggered by the exchange between Samuelson and Kurdas and was published in the successor of the History of Economics Society Bulletin, the Journal of the History of Economic Though (JHET). Blaug took an explicit stance against the "cliophobia" of economists. He transferred Richard Rorty's (1984) distinction of four ways to write the history of philosophy to the history of economic ideas. He identified the first, Geistesgeschichten, with contextual history, the second, historical reconstructions, with interpretations of the ideas of past economists "in their own terms", the third, "rational reconstructions", as a treatment of past thinkers as "contemporaries", the fourth, doxographies, as hagiographical writing that should be avoided. Blaug linked these distinctions to his own earlier distinction between "absolutist" and "relativist" approaches to the history of economic ideas. But Blaug missed the opportunity for a more in-depth discussion of these different labels and limited himself to the observation that the distinction between an absolutist and a reconstructivist stance was "a subtle one" (Blaug 1990, 28).

This is remarkable. We have already seen that the absolutist approach of Economic theory in retrospect entailed: 1) the belief in theoretical progress in economics, and 2) the reconstruction of the logic of old theories in contemporary terms. For Blaug, 2) entailed 1), and this he labelled, following Rorty, rational reconstructivism. We have already seen that 2) does not need to entail 1), and even if we believe 
in theoretical progress, there is no need to reconstruct old theories in modern dress.

This does not mean the only alternative is to use the vocabulary of the past-Blaug's notion of historical reconstruction. Rather, one could show how concepts, methods, and theories developed over time. It is such an approach to the writing of history that one would have expected to find in Blaug's work, but that was conspicuously absent. That is, an approach to the writing of history along the lines of Imre Lakatos's distinction between rational and historical reconstructions. From Blaug's own life history, as from his Methodology of economics, we know how impressed he was with Lakatos's philosophy of science, and so it is a puzzling question why Blaug used Rorty's rather than Lakatos's distinction between rational and historical reconstruction to clarify his historiographical views.

In Lakatos's Proofs and refutations (1976) the notion of a rational reconstruction also refers to the logic of arguments, but does not impose this logic in our modern terms. Rather, Lakatos aimed to show how proofs in mathematics emerge from a dialogue of arguments and counter-arguments in which proofs, concepts and procedures are proposed, challenged, and changed over time. Lakatos thus showed that what might appear as an incontrovertible proof sub specie aeternitatis, could be reconstructed as having a history. However, a rational reconstruction presents a logical sequence of arguments, it does not present these arguments in their historical order of appearance; Lakatos's famous classroom discussion was a rational reconstruction of the actual positions that were held historically. This was Lakatos's distinction between rational and historical reconstructions; a rendering of the logic of the argument versus a rendering of the actual course of events that he famously delegated to the footnotes.

Lakatos's notion of rational reconstruction enables us to see how historical positions can be reconstructed as an exchange of arguments that may lead to the present, but do not need to be framed in modern vocabulary, as in Blaug's (and Samuelson's) notion of rational reconstruction. Lakatos also cut the cake between theoretical substance and context differently than Blaug. For Lakatos, historical reconstructions were about the actual order of historical positions (that might differ from its rational reconstruction). This historical order could (and would) bring in context that would help explain why the historical order of argument differed from its logical reconstruction. 
The first four editions of Blaug's textbook worked with a notion of relativist writing of the history of economic ideas that only in the last edition became equated with a narrowed down notion of historical reconstruction. A relativist writing of the history of economic ideas treated the ideas of historical actors in their own terms, but also discussed contextual factors: "Zeitgeist, social milieu, economic institutions and philosophical currents" (1985 [1962], 7). In the fifth edition, the meaning of historical reconstructions was narrowed down to an understanding of a theory in terms historical actors "would have recognized as a faithful description" of their intentions (1996 [1962], 7). This distinction between rational and historical reconstructions left questions of historical context and order orphaned; they were removed from the introduction's main text to a "note on further reading", and were, as in the earlier editions, hardly treated at all: "There is little in the chapters that follow about Zeitgeist, social milieu or the personalities of the great economists of the past [...] simply because the focus of the present book is on theoretical developments" (1996 [1962], 9). One could equally say that from Blaug's rational reconstructivist viewpoint Economic theory in retrospect was not about theoretical developments at all, but rather presented different theoretical ideas from a presentist perspective.

Historical reconstructions were left into a dead-end, because of the impossibility of discussing past theories "as if we can forget what we now know", but more importantly because it is "literally impossible" to put ourselves in the position of past authors. Thus exactly when Blaug increasingly came to doubt the merits of an absolutist-now rational reconstructivist-way of writing the history of economics in favour of historical reconstructions, he robbed himself of the means of doing so, means that he at least on a Lakatosian reading of the difference between rational and historical reconstructions might have had at his disposal. And thus Blaug's intervention in JHET on the historiography of economics, and the "cliophobia" of economists, turned into a defeat of historical reconstructivism despite Blaug's clearly changed sympathies to the latter.

\section{CheZ VOUS, SANS vOUS}

Most of Blaug's JHET discussion of 1990 focused on the difference between historical and rational reconstructions, in which Blaug clearly found difficulty in defending the first and faulting the last. There was 
nothing wrong with rational reconstructions, or absolutist approaches to the history of economics if the target was the logic of the argument. "Absolutism" was more defendable than "relativism" (Blaug 1990, 28). "Rational reconstructions are perfectly legitimate" (1990, 30). "It is not easy to see how anyone can deny the value of rational reconstructions as such" $(1990,31)$. "There is nothing wrong with this as rational reconstruction" (1990, 32). "Once again, the corn model is a valid rational reconstruction of Ricardo but it is probably not a sound historical reconstruction" (1990, 33). And so on.

Against these sentences, Blaug's well-intended defence of historical reconstruction looked rather bleak. Blaug referred to the discussion between Baumol and Samuelson on the transformation problem, where the balance of arguments was in favour of the rational reconstructivist. Baumol's "historical reconstruction" of Marx was no doubt "correct", but showed that "Marx was only straining to accomplish the impossible", as became clear "with a twinkling of the eye" (Blaug 1990, 29) with Sraffa's rational reconstruction. A historical reconstructivist acted like an econometrician fitting a regression line through obscure and contradicting statements of past authors (1990, 30-31), but Blaug missed the opportunity to point out that on a Lakatosian notion of rational reconstructivism, the obscure and contradicting statements of past authors offered the resources to reconstruct the development of the logic of arguments. Nowhere did Blaug come much further than defending historical reconstructions as an expression of the ideas of past thinkers "in their own terms", but what value added such writing had over those of rational reconstructions in contemporary terms remained unclear. Indeed, on Blaug's own account historical reconstructions bordered on the antiquarian.

Samuelson, just as Blaug, never afraid of a fight, jumped on Blaug's short essay in an exchange of letters between Samuelson, Patinkin, and Blaug. This quickly drifted off into a discussion between Samuelson and Patinkin on whether Samuelson "validly" summarized Cassel's Fundamental thoughts in economics of 1925 in a small model, using Cobb-Douglas production functions and Leontief's "homogeneity postulate”. As with his 'canonical classical model', Samuelson was imposing the vocabulary and assumptions of the modern economist on past authors. Despite Patinkin's reservations against Samuelson's "loose constructionism", he engaged in a discussion of technicalities on Samuelson's proposed model. 
The distinction between rational constructivism, and rational reconstructivism went unnoticed, and it is interesting that Blaug, in the reply to Samuelson with which I started this essay, equally slipped from rational reconstructions to rational constructivism. This last phrase expresses much better what the absolutist or Whig writing of the history of economic ideas is all about. Samuelson was simply imposing a different text; the text of modern economics. In the published correspondence in JHET, Blaug, the historian, was eventually squeezed out of a discussion that had started with an exchange between Samuelson and Blaug. Chez vous, sans vous as the French snapped at the Dutch on the occasion of the signing of the Treaty of Utrecht in 1713 that ended a long century of wars in Europe.

\section{NO MARCH TO PROGRESS}

Blaug's orphaned notion of historical reconstruction left the historian un-armoured. This can be witnessed from a note in the European Journal of the History of Economic Thought of Sraffian Rodolfo Signorino on Blaug's historiographical views. Was a historical reconstruction "a more or less faithful description of what [past thinkers] had set out to do" (Signorino 2003, 329; quoting Blaug), one that gave an account of their ideas "in their own terms" (Blaug 1990, 28)? Signorino could easily point out that giving such an account was turning historical reconstructions into an "empty box". There was no way in which one could circumvent the problem of multiple interpretations, of the baggage an interpreter brought to a text, or-the greatest problem of all-to establish what an earlier thinker "really thought".

On the other end, Signorino signalled that Blaug identified rational reconstructions (just like Samuelson) with Whig history-history written "as a march of progress from past errors to present truths", while an analysis of the logic of an argument-either in the original or in modern terms-in no way entailed such a progressivism. Blaug's grudging counter-note evaded an answer, but I think one of the reasons that Blaug came to prefer the label of rational reconstructions over that of an absolutist writing of the history of economics is because he had lost faith in economics's march to progress, as witnessed best from his acerbic attacks on the increasing formalism (and hence practical irrelevance) of economic theory. But in his reply to Signorino he did not distance himself from the idea of progress in economics. Blaug limited himself to repeating that the only thing "we as historians of ideas ought 
to be aiming for", was historical reconstructions "despite the fact" these were "strictly speaking impossible" (Blaug 2003, 607), and turned to arguments ad hominem by speculating on what was "really motivating Signorino's over-the-top attack", namely Blaug's 1999 attack on the Sraffians $(2003,607)$. But this did not bring Blaug's own polemical arguments in favour of historical reconstructions beyond mere foot stomping.

Blaug's answer to Signorino was clearly not his best showing. If historical reconstructions were "strictly speaking" impossible, Signorino's criticism was simply legitimate and pertinent. But Blaug's narrowing of historical reconstruction to what historical actors "really meant" was not the only alternative available and neither was his presentist notion of rational reconstruction. Earlier, I briefly discussed the possibility that Blaug might have seized upon to develop the notion of rational reconstruction in a Lakatosian direction. Let me, as a conclusion, consider two alternative ways for practicing historical reconstructions.

\section{IDEAS IN CONTEXT}

The two alternatives I will consider were present at the conference of historians at the end of the sixties, embodied in two persons that one may situate at two ends of a scale with ideas on one side and context on the other: Donald Winch and Bob Coats. Put otherwise, Winch and Coats embodied different notions of "context": intellectual and social. Reading the research agenda Bob Coats outlined in the first issue of History of Political Economy, "context" was "social context"; Coats more or less established (historical and contemporary) studies of the sociology of economics.

Yes, it made a difference whether political economy was practiced in the Common Rooms of Oxbridge Colleges, in the London Clubs, in German princely administrations, in Select Committees, in Vienna coffee houses, in academic institutions, in parliaments or Think-Tanks. Despite its weaknesses, Marion Fourcade's recent Economies and societies: discipline and profession in the United States, Britain, and France, 1890s to 1990s (Fourcade 2009) is a good example of history of economics writing that aims to examine how different institutional structures shape different styles of economic practice. ${ }^{4}$ Fourcade wrote a historical

\footnotetext{
${ }^{4}$ See Tribe 2011, and Hodgson 2012, for highly critical reviews of Fourcade's much acclaimed book.
} 
reconstruction of economics that examined the institutional structures of the profession Blaug had relegated to the "notes on further reading". In George Akerlof's words on the back of the book she "demonstrates irrefutably that economists are as much influenced by where they are located as by their supposed adherence to 'scientific method'". Fourcade's book is all about the institutional structures that economists, such as Samuelson, but also historians, such as Blaug, considered peripheral to an understanding of the theories and methods of economists.

Perhaps for that reason Fourcade's book is looked at with distrust by an older generation of historians of economics that shares Blaug's predilection for an understanding of the logical structure of theories and ideas. But also scholars of a younger vintage, such as Ivan Moscati $(2008,86)$, emphasize the importance of logical structure over institutional context. Indeed, according to Moscati, it is only in the texts where the action is. His fear is that a focus on context makes us lose all connection with the economics discipline. And what then are we going to teach our students: no ideas, please, we're historians?

Donald Winch stands for the alternative notion of "context" I want to consider here, intellectual history, just as Quintin Skinner, one of the editors of the renowned Cambridge series 'Ideas in Context'. With his meticulous charting of the intellectual influences on Robert Malthus and dissection of Malthus's reasoning, Winch exemplifies an approach to the history of economics that comes closest to Blaug's answer to Samuelson, "to get as close as possible to what 1776 readers thought of Smith" or to try to "see the past as much as possible as the past saw itself" (Blaug 2003, 607). Winch analyses Malthus's texts in terms that were available to him, and in relation to the economic-socio-political problems he faced and perhaps even tried to influence, and so for those who read Malthus.

The book of Blaug that comes closest to this is without any doubt his first one, the result of his daily visits to the old British Library Reading Room, "reading, reading, reading" and taking notes, Ricardian economics that had as its subtitle: 'a historical study'. If Blaug ever made a historical reconstruction, it is in this book. He examines Ricardo's work in terms available to himself, and then concludes on the textual and contextual evidence available that the Wirkungsgeschichte of Ricardian economics was only limited-much more limited than most economists in the 1950s in search for Giants on whose shoulders they could stand, would have been (and were) willing to admit. 
Marion Fourcade considers herself an economic sociologist, not a historian of economics. Donald Winch is an intellectual historian who does not think of himself as economist. Their work is different from that of the economist. Even though economists may be interested in their work, as Akerlof shows interest in that of Fourcade, or Amartya Sen in that of Winch, such an interest does not earn one a job in an economics department, as it did not for Blaug in the early 1960s. The job article has to be an economics article, in a top mainstream journal, addressing an economists' audience first. Nowadays, it certainly should not be a book. But Mark, the historian, did consider himself an economist first, he wanted to talk to and with economists, he considered the economics profession his first biotope. He considered his reading jury not historians, but economists.

Mark Blaug was, at the end of the day, interested in the arguments of economists, but also remained a man of books in a profession that was increasingly alienated from them. Already in his review of Economic theory in retrospect, H. D. Dickinson (1965) rightly saw the "division between head and heart" that Blaug never solved. History was for Blaug history of ideas, not of social context or research practices. Economists after Samuelson, including Blaug, would automatically take an examination of ideas as a logical, not as a historical exercise, and that came to mean using the logic of contemporary economics.

That determined, in my view, Blaug's ultimate ambivalence on the merit and meaning of historical reconstructions once modern economics had excluded a direct engagement with historical texts as part of its approach to theory, except as a hobbyhorse. As an economist, Blaug was all too well aware there is no place for history in economics. The title of Blaug's (2001) perhaps most programmatic essay exactly captured this: 'No history of ideas, please, we're economists'.

\section{REFERENCES}

Backhouse, Roger E. 2001. Mark Blaug as a historian of economic thought. In Historians of economics and economic thought: the construction of disciplinary memory, eds. Steven G. Medema, and Warren J. Samuels. London: Routledge, 17-39.

Blaug, Mark. 1958. Ricardian economics: a historical study. New Haven: Yale University Press.

Blaug, Mark. 1962. Economic theory in retrospect. Homewood (IL): Richard D. Irwin, Inc. Blaug, Mark. 1980. The methodology of economics, or how economists explain. Cambridge (UK): Cambridge University Press.

Blaug, Mark. 1985 [1962]. Economic theory in retrospect [fourth edition]. Cambridge (UK): Cambridge University Press. 
Blaug, Mark. 1990. On the historiography of economics. Journal of the History of Economic Thought, 12 (1): 27-37.

Blaug, Mark (ed.). 1991. The historiography of economics [Pioneers in Economics Series Vol. 1]. Aldershot (UK): Edward Elgar.

Blaug, Mark. 1996 [1962]. Economic theory in retrospect [fifth edition]. Cambridge (UK): Cambridge University Press.

Blaug, Mark. 2003. Rational vs. historical reconstruction: a counter-note on Signorino's note on Blaug. European Journal of the History of Economic Thought, 10 (4): 607608.

Blaug, Mark. 2001. No history of ideas, please, we're economists. Journal of Economic Perspectives, 15 (1): 145-164.

Boulding, Kenneth E. 1971. After Samuelson who needs Adam Smith. History of Political Economy, 3 (2): 225-237.

Boumans, Marcel J. 2005. How economists model the world into numbers. New York and London: Routledge.

Davis, John B. 2013. Mark Blaug on the historiography of economics. Erasmus Journal for Philosophy and Economics, 6 (3): 44-63. http://ejpe.org/pdf/6-3-art-3.pdf

De Marchi, Neil B. 1988. The Popperian legacy in economics. Papers presented at a symposium in Amsterdam, December 1985. Cambridge: Cambridge University Press.

De Marchi, Neil B. 2002. Putting evidence in its place: John Mill's early struggles with "facts in the concrete". In Fact and fiction in economics: models, realism, and social construction, ed. Uskali Mäki. Cambridge: Cambridge University Press, 305-328.

Dickinsin, Henry D. 1965. Review of 'Economic theory in retrospect'. The Economic Journal, 75 (297): 168-170.

Fountain, John. 2007. A conversation with Mark Blaug. University of Canterbury. http://youtu.be/cEzcLkpuhmw (accessed 15 December 2013).

Fourcade, Marion. 2009. Economists and societies: discipline and profession in the United States, Britain, and France, 1890s to 1990s. Princeton (NY): Princeton University Press.

Hands, D. Wade. 2007. A tale of two mainstreams: economics and philosophy of natural science in the mid-twentieth century. Journal of the History of Political Economy, 29 (1): 1-13.

Hodgson, Geoffrey M. 2010. Review in 'review symposium' on Marion Fourcade: Economists and societies: discipline and profession in the United States, Britain, and France, 1890s to 1990s. Socio-Economic Review, 8 (4): 747-764.

Kurdas, Cigdem. 1988. The "Whig historian" on Adam Smith: Paul Samuelson's canonical classical model. History of Economics Society Bulletin, 10 (1): 13-23.

Maas, Harro. 2011. The economist as an armchair observer. In Histories of scientific observation, eds. Lorraine Daston, and Elisabeth Lunbeck. Chicago: University of Chicago Press, 206-229.

Morgan, Mary S. 2012. The world in the model: how economists work and think. Cambridge and New York: Cambridge University Press.

Moscati, Ivan. 2008. More economics, please: we're historians of economics. Journal of the History of Economic Thought, 30 (1): 85-91.

Nagel, Thomas. 1986. The view from nowhere. Oxford: Oxford University Press. 
Rorty, Richard. 1984. The historiography of philosophy: four genres. In Philosophy in history: essays in the historiography of philosophy, eds. R. Rorty, J. B. Schnewind, and Q. Skinner. Cambridge: Cambridge University Press, 49-76.

Samuelson, Paul A. 1947. Foundations of economic analysis. Cambridge (MA): Harvard University Press.

Samuelson, Paul A. 1948. Economics. New York: McGraw-Hill.

Samuelson, Paul A. 1978. The canonical classical model. Journal of Economic Literature, 16 (4): 1415-1434.

Samuelson, Paul. A. 1987. Out of the closet: a program for the Whig history of economic science. History of Economics Society Bulletin, 9 (1): 51-60.

Samuelson, Paul A. 1988. Keeping Whig history honest. History of Economics Society Bulletin, 10 (2): 161-167.

Samuelson, Paul A., Don Patinkin, and Mark Blaug. 1991. On the historiography of economics: a correspondence. Journal of the History of Economic Thought, 13 (2): 144-158.

Signorino, Rodolfo. 2003. Rational vs historical reconstructions: a note on Blaug. The European Journal of the History of Economic Thought, 10 (2): 329-338.

Stigler, George J. 1965. Textual exegesis as a scientific problem. Economica, 32 (128): 447-450.

Stigler, George J. 1969. Does economics have a useful past? History of Political Economy, 1 (2): 217-230.

Tribe, Keith. 2001. Economists and societies: discipline and profession in the United States, Britain, and France, 1890s to 1990s. History of Political Economy, 43 (3): 620-623.

Harro Maas is an associate professor at Utrecht University. He published widely in history and methodology of the economics, from the early modern period to the econometric revolution in the Interwar period, and especially in the history of political economy in Victorian Britain. His book on one of the founders of modern economics, William Stanley Jevons (Cambridge University Press, 2005) was awarded the Joseph J. Spengler prize by the (American) History of Economics Society. Economic methodology: an historical introduction will appear with Routledge in February 2014. With Mary S. Morgan (LSE), he co-edited the History of Political Economy (HOPE) annual supplement of 2012 Observing the economy: historical perspectives.

Contact e-mail: <h.b.j.b.maas@uu.nl>

Website: <http://www.uu.nl/leg/staff/HBJBMaas> 